\title{
A rare but important differential diagnosis in transient monocular blindness
}

\author{
Raman Mehrzad,' Rishi Bajaj²
}

'Department of Medicine, Steward Carney Hospital, Tufts University School of Medicine, Boston, Massachusetts, USA Department of Cardiology, Saint Vincent Hospital, University of Massachusetts Medical School, Worcester, Massachusetts, USA

\section{Correspondence to}

Dr Raman Mehrzad, raman_m1@hotmail.com

Accepted 3 October 2014

\section{DESCRIPTION}

A 45-year-old man presented with transient episodes of monocular blindness. Physical examination, including full neurology and funduscopy examination was unremarkable. Head CT was negative for intracranial bleed. Carotid ultrasound with Doppler was unremarkable. A twodimensional echocardiogram was performed and showed a mobile mass attached to the aortic valve. To further evaluate the mass, a transesophageal echocardiography (TEE) was performed which showed a multilobulated, mobile, pedunculated mass attached to the aortic surface of the noncoronary aortic cusp, measuring $1.5 \mathrm{~cm} \times 0.4 \mathrm{~cm}$ without any valvular involvement (figure 1 and video 1 ). Via thoracotomy, the mass was surgically excised. Aortic valve competence was confirmed intraoperatively before the aortotomy was closed. Gross examination showed a pedunculated mass with frond-like projections and filamentous endings, appearing like a 'sea anemone' (figure 2). Histopathology revealed branching avascular papillae with single layer of endothelium, confirming the diagnosis of papillary fibroelastoma (PFE; figure 3). No symptomatic recurrence or evidence of regurgitation was seen on follow-up at 6 months.

PFEs are rare cardiac tumours, but should be differentiated from thrombus, vegetation, myxoma and Lambl's excrescence. ${ }^{1}$ Although patients are typically asymptomatic, PFEs can potentially lead to severe complications, primarily due to their embolic potential. A TEE most often helps in making a presumptive diagnosis. ${ }^{2}$ Surgical excision is curative and is indicated in symptomatic patients, lesions larger than $1 \mathrm{~cm}$, and in patients with leftsided lesions. ${ }^{3}$ Our case underscores the

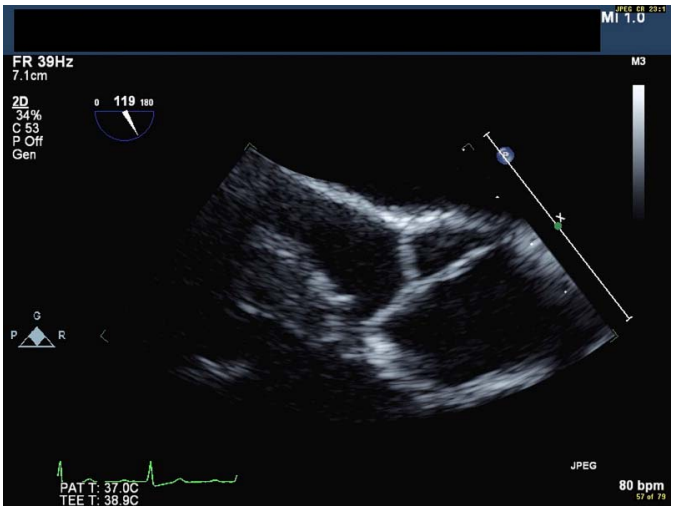

To cite: Mehrzad R, Bajaj R. BMJ Case Rep Published online: [please include Day Month Year] doi:10.1136/bcr-2014206812

CrossMark

Figure 1 Transesophageal echocardiographic image of aortic valve. importance of PFE in the differential diagnosis of transient blindness, especially in young patients without significant medical histories.

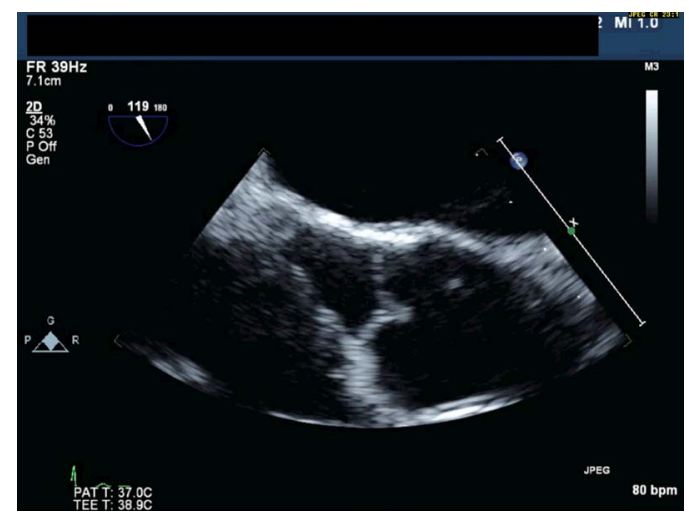

Video 1 TEE showing a multilobulated, mobile, pedunculated mass attached to the aortic surface of the noncoronary aortic cusp.

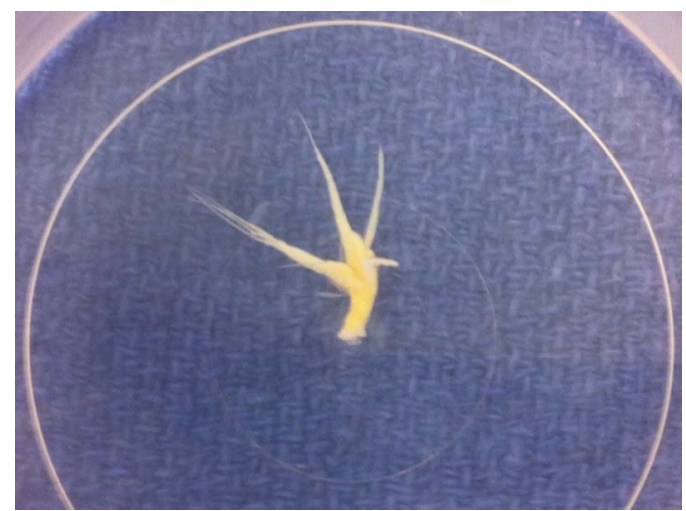

Figure 2 Gross examination showing pedunculated mass with frond like projections and filamentous endings appearing as 'sea anemone'.

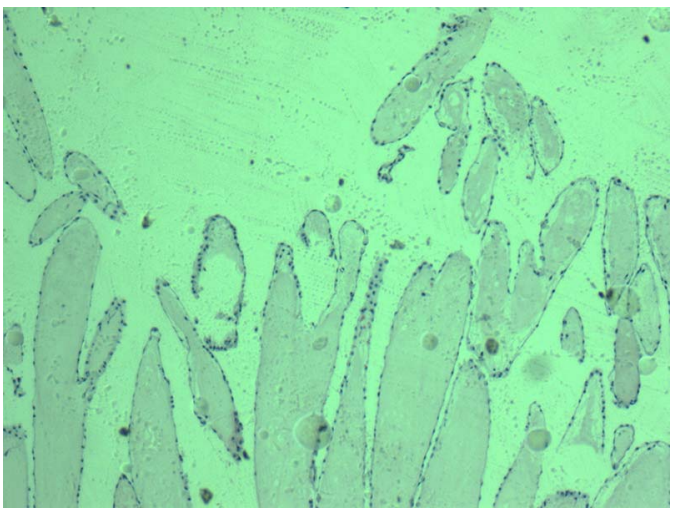

Figure 3 Histopathological examination showing 


\section{Learning points}

Papillary fibroelastoma are rare cardiac tumours, typically found on the heart valves, that has the embolic potential.

- A transesophageal echocardiography will help diagnose them and they should be differentiated from thrombus, vegetation, myxoma and Lambl's excrescence.

- Surgical excision is curative and is indicated in symptomatic patients, lesions larger than $1 \mathrm{~cm}$, and in patients with left-sided lesions.
Contributors Both authors reviewed the scientific literature, interpreted the data, and wrote the manuscript.

Competing interests None.

Patient consent Obtained.

Provenance and peer review Not commissioned; externally peer reviewed.

\section{REFERENCES}

1 Aryal MR, Badal M, Mainali NR, et al. Papillary fibroelastoma of the aortic valve: an unusual cause of angina. World I Cardiol 2013;5:102-5.

2 Fine NM, Foley $\mathrm{DA}, \mathrm{Breen} \mathrm{JF}$, et al. Multimodality imaging of a giant aortic valve papillary fibroelastoma. Case Rep Med 2013;2013:705101.

3 Zhang $M$, Liu $X$, Song Z, et al. Cardiac papillary fibroelastoma: a retrospect of four cases. J Cardiothorac Surg 2013;8:65.

Copyright 2014 BMJ Publishing Group. All rights reserved. For permission to reuse any of this content visit http://group.bmj.com/group/rights-licensing/permissions.

BMJ Case Report Fellows may re-use this article for personal use and teaching without any further permission.

Become a Fellow of BMJ Case Reports today and you can:

- Submit as many cases as you like

- Enjoy fast sympathetic peer review and rapid publication of accepted articles

- Access all the published articles

- Re-use any of the published material for personal use and teaching without further permission

For information on Institutional Fellowships contact consortiasales@bmjgroup.com

Visit casereports.bmj.com for more articles like this and to become a Fellow 